\title{
Disturbance sources, human predation and reproductive success of seabirds in tropical coastal ecosystems of Sinaloa State, Mexico
}

\author{
A. MUÑOZ DEL VIEJO, X. VEGA, M. A. GONZÁlez and \\ J. M. SÁNCHEZ
}

\section{Summary}

From March to July 2000, four seabird colonies in coastal ecosystems of Sinaloa, northwest Mexico were visited: on islets, a sandy beach and a long-abandoned salt-panning flat. There were partial and total breeding failures, most of them due to human activity. Amongst colonies of nine species, the breeding success of three was severely affected. All 250 Royal Tern Sterna maxima eggs were taken for direct consumption; 50\% (75) of Bluefooted Booby Sula nebouxii chicks were killed for crab (Portunidae) fishing; and in a Least Tern Sterna antillarum colony (97 pairs), 50\% failed due to disturbance from a fishing championship. Some of these species have priority status within Mexican and international conservation regulations. Certain aspects of these problems are discussed, and actions are suggested to balance conservation and the development of economic activities.

\section{Introduction}

Natural and human disturbance are important components of many ecosystems, and variations in disturbance can affect the whole ecosystem, as well as the structure and functioning of the communities that form it (Hobbs and Huenneke 1992, Griffiths and van Schaik 1993, Kerr and Currie 1995). During the nesting phase of seabird breeding in coastal wet zones (saltmarshes, islands, sandbars, etc.), predation and disturbance (human activity, vandalism, commercial exploitation, environmental contamination, parasitism and disease, inclement weather and flooding) often cause a drop in reproductive success. There can even be total failure, with a consequent progressive decline in population size (Burger and Gochfeld 1996, Gochfeld and Burger 1996, Hockey 1996, Piersma 1996, Zusi 1996, Oltra and Gómez 1997). Furthermore, there are other factors, such as kleptoparasitism and interactions with other vertebrates (Burger and Gochfeld 1990, 1991), that are of concern to the conservation of threatened species.

Predation is an important factor affecting seabird reproduction (Lack 1968, Burger and Gochfeld 1994). During breeding, seabird eggs or chicks are preyed on by a range of predators, including mammals, other birds and reptiles (Burger 1985, Wittenberger and Hunt 1985, Gaston and Masselink 1997, Yorio and Quintana 1997), invertebrates (e.g. ants: Nisbet and Welton 1984, Burger and Gochfeld 1990, 1991, Safina et al. 1994) and also some crab species, such as Ocypode quadrata (Gochfeld and Burger 1996). The presence of certain predators can be the determining factor in colony site selection (Erwin et al. 1998), with sites far from the coast being chosen where predator incidence is almost nil 
(Burger and Gochfeld 1991). In some cases, natural or human disturbance also determines nest-site selection (Erwin et al. 1998). Frequently, previous nesting in a given area is a good indicator of habitat quality (Burger 1982, Klopfer and Ganzhorn 1985, Burger and Gochfeld 1990, Danchin and Monnat 1992, Nager et al. 1996). Furthermore, knowledge of previous and/or neighbouring reproductive success (even of other species) can affect colonial nest-site selection (Boulinier et al. 1996, Boulinier and Danchin 1997). In this sense, Ziewitz et al. (1992) suggested that there are two principal factors (destruction and loss of habitat, and alteration of nestling rearing conditions) that are the most important threats to seabirds, especially when the species is threatened.

In this study, we quantified the impact of disturbance on the breeding success in colonies of seabird species in different ecosystems on the Mexican Pacific Coast (Sinaloa State). The species involved were Blue-footed Booby Sula nebouxii, Laughing Gull Larus atricilla, Least Tern Sterna antillarum, Royal Tern Sterna maxima, Gull-billed Tern Sterna nilotica, Black Skimmer Rynchops niger, American Oystercatcher Haematopus palliatus, Snowy Plover Charadrius alexandrinus and Wilson's Plover Charadrius wilsonia. None are listed as globally threatened (BirdLife International 2000), but, in the conservation laws of Mexico and other countries of North America, some are listed as threatened or endangered: Blue-footed Booby (Threatened: CONABIO 2000); Snowy Plover (Threatened: USFWS 2000); and Least Tern (Endangered: CONABIO 2000, USFWS 2000). We also aimed to address the issues involved and put forward some tentative ideas to mitigate the incidence of human disturbances on seabird reproductive biology, and improve the conservation conditions of these and similar species.

\section{Study areas and methods}

The coastal ecosystems of Sinaloa State are unanimously considered very important zones for many wintering North American migratory birds (Engilis et al. 1998), but the status of other migratory and breeding species endangered in North America is almost completely unknown. From March to July 2000, we visited four coastal localities of Sinaloa State. There were three habitats where colonial seabirds nested: islets, a sandy beach and a long-abandoned saltpanning flat. The two islets were El Rancho Island $\left(25^{\circ} \mathrm{Og}{ }^{\prime} \mathrm{N}-108^{\circ} 22^{\prime} \mathrm{W}\right)$ and Melendres Island $\left(24^{\circ} 49^{\prime} \mathrm{N}-108^{\circ} \mathrm{O} 4^{\prime} \mathrm{W}\right)$. The sandy ocean beach was Punta Yameto $\left(24^{\circ} 45^{\prime} \mathrm{N}-108^{\circ} \mathrm{O} 2^{\prime} \mathrm{W}\right)$ and the saltflat was at Ceuta Bay $\left(23^{\circ} 57^{\prime} \mathrm{N}-\right.$ $\left.106^{\circ} 59^{\prime} \mathrm{W}\right)$. All sites had a sandy substratum, irregularly covered by halophilous vegetation, except at Ceuta Bay, where birds nested on a substratum of salt (Figure 1).

The Punta Yameto colony had a more or lest rectangular form, with a surface of 2.25 ha $(300 \times 75 \mathrm{~m})$. The sandy substratum had many bivalve shell remains. This area was bounded by the shoreline and by a sandy dune-bar with variable vegetation density. At Ceuta Bay, the colony was on a substratum of salt, and the nesting area extended on some long-abandoned salt-panning flats, with an approximate total surface of 50 ha, next to a large, shallow and calm bay. This area was separated from the beach by a long and narrow zone of caducifolious shrub dry forest. El Rancho and Melendres islands had irregular forms, with an approximate surface of 120 ha and 60 ha respectively. Both had a sandy 


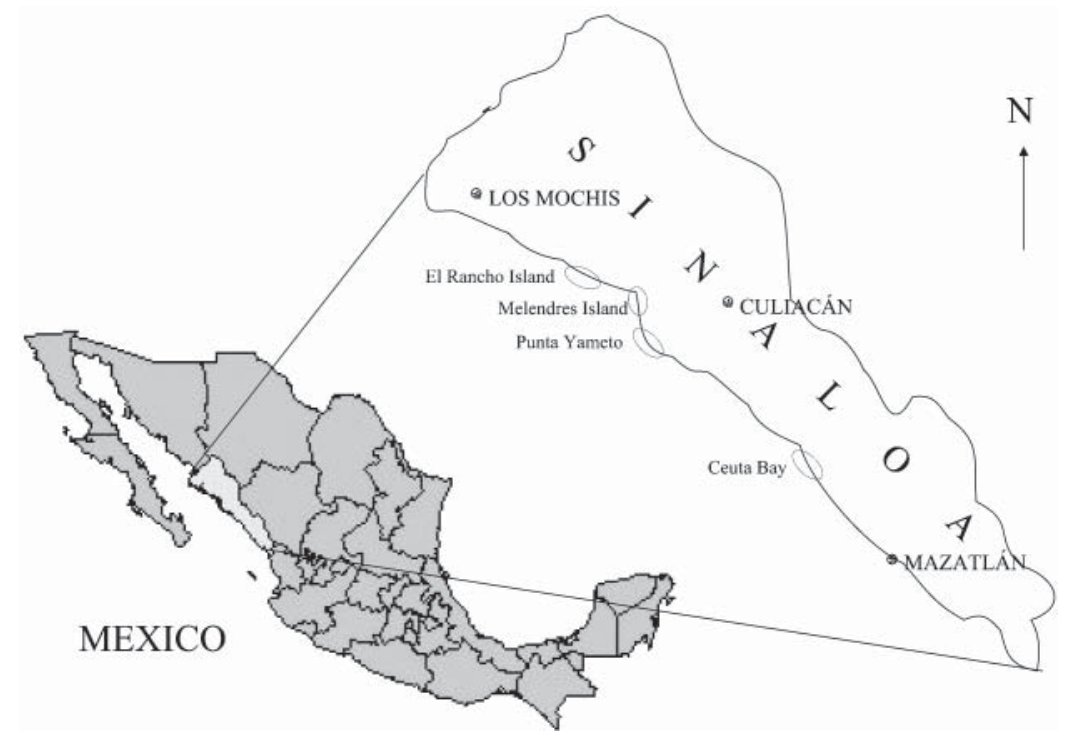

Figure 1. Geographic location of the seabird colony sites studied in Sinaloa State, Mexico.

substratum, and there were small elevations with herbaceous vegetation where Laughing Gulls nested. Royal Terns nested in elevated zones without vegetation. Gull-billed Terns, American Oystercatchers, Black Skimmers and Blue-footed Boobies nested on non-elevated sandy substratum.

At weekly intervals we censused the adults, and also located nests and marked them with a $40 \mathrm{~cm}$ wooden stake, placed $0.5 \mathrm{~m}$ from the nest. We examined nest status (species, number of eggs and/or nestlings and fledglings), and calculated hatching success. We categorized the clutch success as real or probable, according to whether or not we had recorded hatching. Because visits were made at weekly intervals, it was necessary to estimate the losses due to each cause to the nearest $10 \%$.

\section{Results}

We distinguished seven factors that caused total or partial breeding failure of colonies: (1) predation by terrestrial mammals, mainly coyotes Canis latrans and feral dogs; (2) intraspecific predation of eggs and/or nestlings by Laughing Gulls; (3) movement of livestock (cows); (4) human entry, on foot or in vehicles; (5) direct harvesting of eggs for human consumption; (6) killing of fledglings by fishermen; and (7) accidental flooding.

\section{Predation}

At Ceuta Bay, the site's conditions allowed easy access for terrestrial predators, mainly coyotes. Predators caused 30\% of the breeding failures for the three species present: Least Tern, Snowy Plover and Wilson's Plover (Table 1). 
A. Muñoz del Viejo et al.

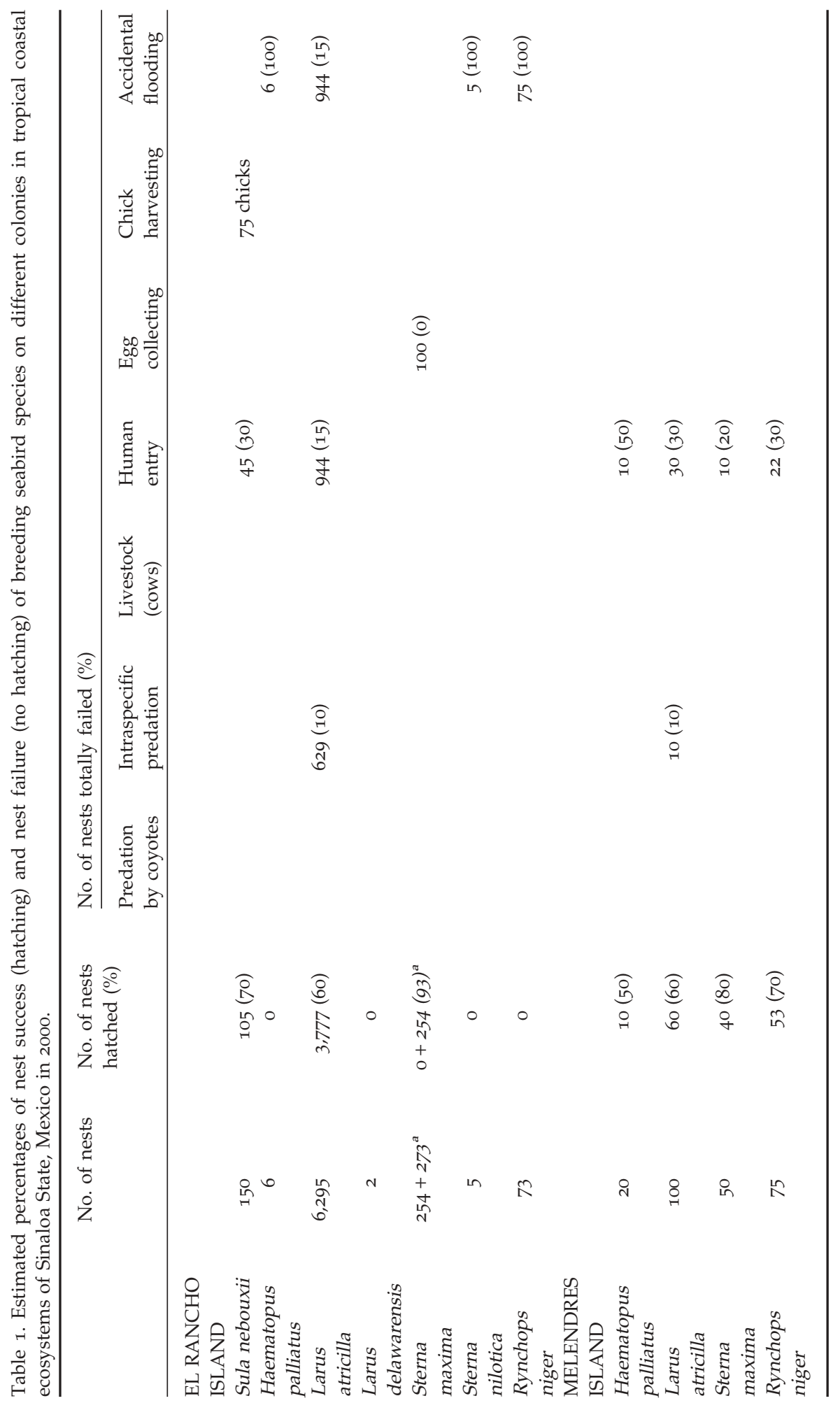




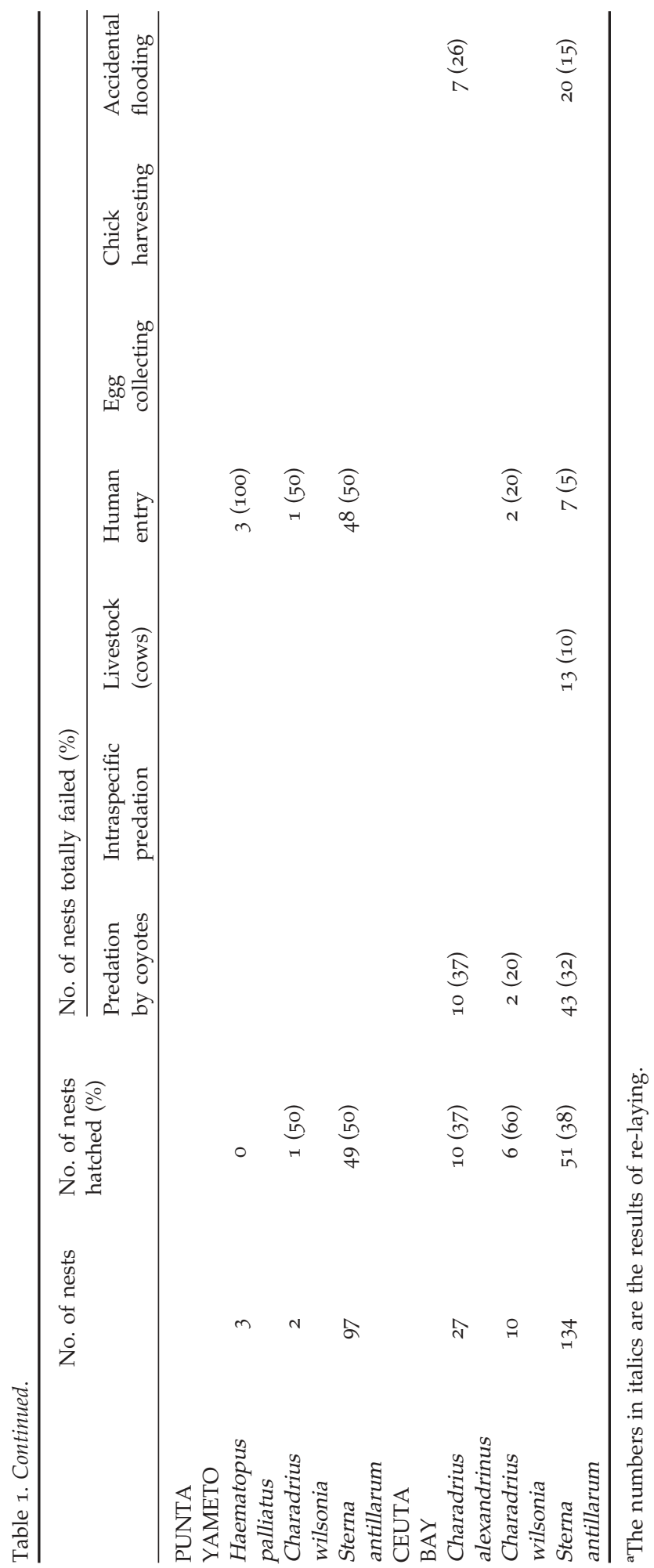




\section{Intraspecific predation}

El Rancho and Melendres islands had mixed colonies, with an overwhelming dominance by Laughing Gulls. There was a mean of $1.76 \pm 0.81 \quad(n=261)$ hatchlings per nest for Laughing Gulls. Eggs and nestlings were subject to intraspecific predation, and we determined that this factor caused $10 \%$ of the losses in eggs and/or nestlings of this species (Table 1 ).

\section{Movement of livestock}

The conditions at Ceuta Bay allowed easy access for livestock (cows) and their herdsmen. They wandered occasionally onto the colony, trampling some nests. This affected Least Tern, the most abundant species at the site, causing losses of $10 \%$ of clutches and/or broods (Table 1 ). No livestock were recorded at Punta Yameto beach or on Melendres and El Rancho islands.

\section{Human entry, on foot or in vehicles}

Human entry was the most widespread factor affecting all four colonies studied. The level of intrusion varied in relation to the colony's accessibility. On the islands, almost all species suffered losses of $15-30 \%$, by nest and/or brood abandonment. The causes of these losses were passing outboard motorboats, and the mooring of boats on the shore for the fishermen to rest, amongst various other human activities (Table 1 ).

At the sandy beach of Punta Yameto, a fishing competition over a weekend caused the destruction of half the nests and the disappearance of half the nestlings by trampling and disturbance. Afterwards, adverse weather conditions (mainly westerly winds) made it impossible for the adults to re-lay.

\section{Direct harvesting of eggs for human consumption}

For Royal Terns on El Rancho Island, the most important source of disturbance was human activity. During Easter Week, a group of local people harvested all the Royal Tern eggs. According to the villagers, Royal Tern is called "Little Cock", and their eggs are highly nutritive and restorative (especially for hangovers). Afterwards, the Royal Tern population recovered and laid new clutches in nearby zones, with a hatching success of $90 \%$ (Table 1 ).

\section{Fledgling killing by fishermen}

On El Rancho Island, 75 Blue-footed Booby fledglings were killed by fishermen to obtain groundbait to fish for crabs Portunidae. This caused a decline of at least $50 \%$ in the colony (Figure 2, Table 1 ).

\section{Accidental flooding}

Accidental flooding was the only non-human factor that affected the colonies, apart from predation. It mainly affected non-island colonies, but on El Rancho 


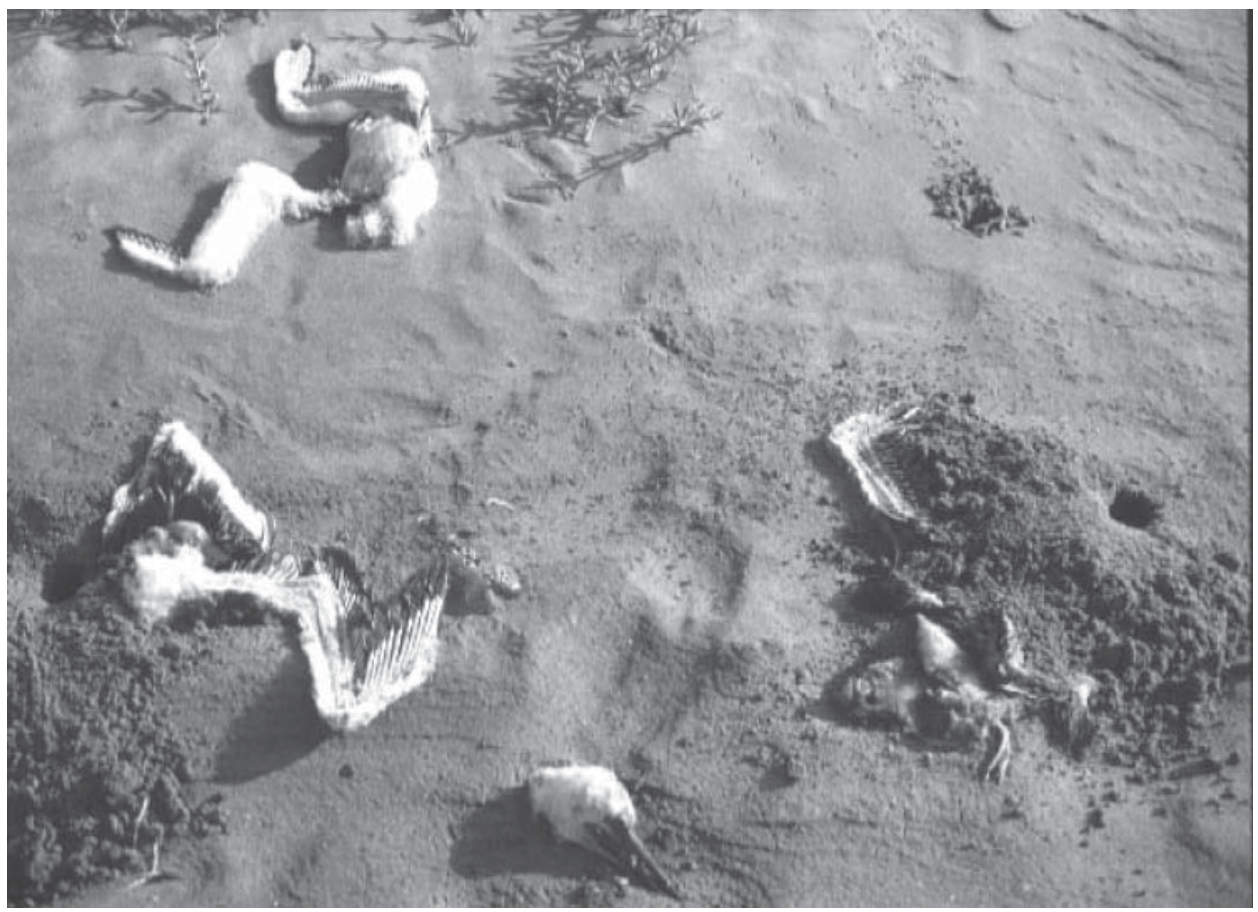

Figure 2. Blue-footed Booby chicks killed by fishermen.

Island, Laughing Gulls were subjected to flooding caused by a storm in $15 \%$ of the nests. The same storm caused total failures in Black Skimmers, American Oystercatchers and Gull-billed Terns. Ceuta Bay, the long-abandoned saltflat located between a coastal sand-bar and the mainland, was subjected to total flooding at the end of the breeding season. The persistent rains caused the total failure of $30 \%$ of Least Tern clutches and 35\% of Snowy Plover clutches (Table 1).

\section{Discussion}

There were partial and total breeding failures, most of them due to human activity. Amongst colonies of nine species, the breeding success of three was severely affected: all 250 Royal Tern eggs were taken for direct consumption; $50 \%$ (75) of Blue-footed Booby chicks were killed for crab fishing; and in a Least Tern colony of 97 pairs, 50\% failed due to disturbance from a fishing championship.

\section{Predation}

Aerial predators are considered to be the most dangerous for colonial seabirds, especially on islands (Burger and Gochfeld 1990). In this study, few aerial predators were present, but we did observe an undetermined amount of intraspecific predation among Laughing Gulls at Melendres and El Rancho islands, as has previously been described in colonial species (Wittenberg and Hunt 1985). 
For Little Terns Sterna albifrons in Korea, Hong et al. (1998) indicated that low density in the colony encouraged the presence of aerial predators, because there was a weakening of group defence strategies. In this case, it is necessary to take into account that the eggs are cryptic with respect to the ground, so that they are not easily visible from the air, but are still accessible to terrestrial predators. The Least Tern nests in Punta Yameto were even more cryptic because this sandy beach had many washed-up bivalve shells. Mean nest density was $16.71 \pm 3.79$ nest/ha, and there was no evidence of aerial predation and no evidence of nest defence. These results may be relevant in the debate about the importance of nest density or colony size as a factor in strategies against predation (Anderson and Hodum 1993, Oro 1996, Brunton 1999).

On sandy beaches and saltmarshes, seabird species would be more exposed to terrestrial predators, mainly mammals (Burger and Gochfeld 1991). The only mammals of proven occurrence were coyotes, which caused 33\% of nest losses at Ceuta Bay. This is an important fact given that two of the species nesting there are listed as threatened in Mexico and North America (CONABIO 2000, USWFS 2000).

Human disturbance and activities increase predation risk in colonies (King et al. 1992, Licht and Johnson 1992). Many human activities involve the additional presence of predators (cats, dogs, coyotes, raccoons, etc.) and/or other species that destroy the nests such as livestock (Burger and Gochfeld 1990, Brunton 1999). This was the case at the saltflat of Ceuta Bay, where livestock (cows) trampled many Least Tern and plover nests.

The islands should be free of mammal predation, as was the case at El Rancho and Melendres, where there was no evidence of terrestrial depredation, but we recorded mobbing as a form of colonial defence by Laughing Gulls and Royal Terns against potential terrestrial predators (ourselves). As Burger and Gochfeld (1991) showed in Common Tern, mobbing is the most common form of group defence, and can involve several birds or the entire colony dive-bombing and attacking a predator, often escorting it from the colony.

\section{Human disturbance}

Human disturbance can be direct, affecting eggs, chicks and adults, or indirect, causing interruption of incubation, exposure to environmental factors or to predators, or affecting nestling care (Burger and Gochfeld 1991, Vidal and Domínguez 2000). As was shown by Burger and Gochfeld (1990), human intrusion was a common problem at the sandy beach colonies (Punta Yameto). Anglers, tourists and drivers of $4 \times 4$ vehicles caused nest destruction, broken eggs and high chick mortality. In this sense, Least Tern's preference for sandbars on beaches leads to conflict with human use (Gochfeld 1983, Brunton 1997), and this is one of the factors that may explain their frequent selection of non-optimal habitats for nesting (Thompson and Slack 1982). However, islands were not free from these problems. The constant circulation of boats and people around the shore disturbed colonies at both Melendres and El Rancho. There have been similar findings for some of these and other species (King et al. 1992, Klein et al. 1995, Burger 1998). 
Human predation was another factor affecting eggs and chicks. Local people collect eggs for their own consumption or for commercial exploitation, and even kill chicks for various reasons, including vandalism (Burger and Gochfeld 1999, 1991). This factor was the cause of the total failure of the Royal Tern first clutches, and the death of 75 Blue-footed Booby chicks at El Rancho island.

\section{Flooding}

Flooding is always a risk to ground-nesting coastal species, especially at former saltflats (Burger and Gochfeld 1991, Erwin et al. 1998), as indeed occurred at Ceuta Bay. García and Ceballos (1995) described this phenomenon for Least Tern on the Jalisco coast (Mexico). In the process of nest-site selection, some species appear to evaluate the flooding risk in a given zone, and then often situate the nests in areas with vegetation, which are potentially less exposed to flooding (Burger and Gochfeld 1991). On the two islands, with the exception of Black Skimmers, Gull-billed Terns and American Oystercatchers, the birds indeed situated their nests in areas with low flooding risk, and the losses from flooding were not significant, especially for Laughing Gulls and Royal Terns.

\section{Conservation measures}

We have shown that, in spite of the apparent advantage of nesting on islands because of fewer terrestrial predators and lower human disturbance levels (Powell and Cuthbert 1992), seabird colonies in coastal zones, whether on islands or not, are not free from human disturbance. In some cases, quite minimal local management action can contribute to mitigating some risk factors: restricting vehicle and individual access to beaches and nesting zones (King et al. 1992, Klein et al. 1995, Brunton 1997); limiting the approach of boats to island shorelines (Powell and Cuthbert 1992, Burger 1998); directly and permanently protecting the nesting zones (Burger and Gochfeld 1991, García and Ceballos 1995); raising islands and sandbars near saltflats to defend against flooding (Ziewitz et al. 1992, Erwin et al. 1998); and developing programmes of environmental education with local people (Burger and Gochfeld 1991).

In this case, there are no real possibilities for habitat management, but conservation zones could be defined to include other zones that have already been established for other species, such as Olive Ridley sea turtles Lepidochelys olivacea (García and Ceballos 1995). Some species select especially conflictive zones, which are now urban areas or have attracted human recreation (Simmons et al. 1998). A possible strategy in planning conservation measures in this type of situation would be environmental education and arousal of the interest (both cultural and economic) of local people. In this sense, the re-laying success of the Royal Tern colony and the halt of the booby chick harvesting were achieved by us arranging meetings with fishermen from different towns of Santa María Bay, the location of El Rancho island. Moreover, as additional strategies, one could use the declaration of a Reserved Zone for other species, which already has a precedent in Mexico (García and Ceballos 1995), such as the aforementioned case of Ceuta Beach for Olive Ridley sea turtles, or the programmes of Integral Management of certain areas, such as the Santa María Bay Project (Conservation International, Mexico, A.C., pers. comm.). 


\section{Acknowledgements}

We would like to thank Michael Gochfeld and Seb Buckton for their valuable comments and suggestions on the manuscript. This study was made during a stay by A. Muñoz del Viejo at the Universidad Autónoma de Sinaloa, in the "Programa de Incorporación de Doctores Españoles a Universidades Mexicanas" (ANUIES, Mexico, and AECI, Spain). The work is a part of the "Programa de Conservación de Aves del Noroeste de México" (MANOMET Center of Conservation Sciences). For the field work, we had the generous help of FUSBIO personnel, PROFEPA agents, fishermen of Costa Azul, Playa Colorada, La Reforma and Punta Yameto, Navolato Municipal Government, Tony Pico and, last but not least, Cecilia del Rocío Hermández.

\section{References}

Anderson, D. J. and Hodum, P. J. (1993) Predator behavior favors clumped nesting in an oceanic seabird. Ecology 74: 2462-2464.

BirdLife International (2000) Threatened birds of the world. Barcelona and Cambridge, U.K.: Lynx Edicions and Bird Life International.

Boulinier, T. and Danchin, E. (1997) The use of conspecific reproductive success for breeding patch selection in terrestrial migratory species. Evol. Ecol. 11: 505-517.

Boulinier, T., Danchin, E., Monnat, J.-Y., Doutrelant, C. and Cadiou, B. (1996) Timing of prospecting and the value of information in a colonial breeding species. J. Avian Biol. 27: 252-256.

Brunton, D. H. (1997) Impacts of predators: center nest are less successful than edge nest in a large nesting colony of Least Terns. Condor 99: 372-380.

Brunton, D. H. (1999) "Optimal" colony size for the Least Terns: an intercolony study of opposing selective pressures by predators. Condor 101: 607-615.

Burger, J. (1982) The role of reproductive success in colony-site selection and abandonment in Black Skimmers (Rynchops niger). Auk 99: 109-115.

Burger, J. (1985) Advantages and disadvantages of mixed-species colonies of seabirds. Proc. Int. Orn. Congr. XVIII: 905-918.

Burger, J. (1998) Effects of motorboats and personal watercraft on flight behavior over a colony of Common Terns. Condor 100: 528-534.

Burger, J. and Gochfeld, M. (1990) The Black Skimmer: social dynamics of a colonial species. New York: Columbia University Press.

Burger, J. and Gochfeld, M. (1991) The Common Tern: its breeding biology and social behavior. New York: Columbia University Press.

Burger, J. and Gochfeld, M. (1994) Predation and effects of humans on islands nesting seabirds. Pp. 39-67 in D.N. Nettleship, J. Burger and M. Gochfeld, eds. Seabirds on islands. Threat, case studies and action plans. Cambridge, U.K.: BirdLife International (BirdLife Conservation Series no. 1).

Burger, J. and Gochfeld, M. (1996) Family Laridae (Gulls). Pp. 572-623 in J. del Hoyo, A. Elliot and J. Sargatal, eds. Handbook of the birds of the world. Vol. 3. Hoatzin to Auks. Barcelona: Lynx Edicions.

CONABIO (2000) Norma Oficial Mexicana NOM-ECOL-059-1994, que determina las especies y subespecies de flora y fauna silvestres terrestres y acuáticas En Peligro de Extinción, Amenazadas, Raras y las sujetas a Protección Especial y que establece especificaciones para su protección (actualizada en 1997). Available at: http// www.conabio.gob.mx

Danchin, E. and Monnat, J.-Y. (1992) Population dynamics modeling of two neighboring Kittiwake Rissa tridactyla colonies. Ardea 80: 171-180. 
Engilis, A. Jr, Oring, L. W., Carrera, E., Nelson, J. W. and Martínez López, A. (1998) Shorebird surveys in Ensenada Pabellones and Bahía Santa María, Sinaloa, Mexico: critical winter habitats for Pacific flyway shorebirds. Wilson Bull. 110: 332-341.

Erwin, R. M., Nichols, J. D., Eyler, T. B., Stotts, D. B. and Truitt, B. R. (1998) Modeling colony-site dynamics: a case study of Gull-billed Terns (Sterna nilotica) in coastal Virginia. Auk 115: 970-978.

García, A. and Ceballos, G. (1995) Reproduction and breeding success of California Least Terns in Jalisco, Mexico. Condor 97: 1084-1087.

Gaston, A. J. and Masselink, M. (1997) The impact of Raccoons on breeding seabirds at Englefield Bay. Bird Conserv. Int. 7: 35-51.

Gochfeld, M. (1983) Colony site selection by Least Terns: physical attributes of sites. Colonial Waterbirds 6: 205-213.

Gochfeld, M. and Burger, J. (1996) Family Sternidae (Terns). Pp. 624-667 in J. del Hoyo, A. Elliot and J. Sargatal, eds. Handbook of the birds of the world. Vol. 3. Hoatzin to Auks. Barcelona: Lynx Edicions.

Griffiths, M. and van Schaik, C. P. (1993) The importance of human traffic on the abundance and activity periods of Sumatran rain forest wildlife. Conserv. Biol. 7: $623-626$.

Hobbs, R. J. and Huenneke, L. F. (1992) Disturbance, diversity, and invasion: implications for conservation. Conserv. Biol. 6: 324-337.

Hockey, P. A. R. (1996) Family Haematopodidae (Oystercatchers). Pp. 308-325 in J. del Hoyo, A. Elliot and J. Sargatal, eds. Handbook of the birds of the world. Vol. 3. Hoatzin to Auks. Barcelona: Lynx Edicions.

Hong, S.-B., Vood, Y.-T. and Higashi, S. (1998) Effects of clutch size and egg-laying order on the breeding success in the Little Tern Sterna albifrons on the Nakdong Estuary, Republic of Korea. Ibis 140: 408-414.

Kerr, J. T. and Currie, D. J. (1995) Effects of human activity in global extinction risk. Conserv. Biol. 9: 1528-1538.

King, B. R., Hicks, J. T. and Cornelius, J. (1992) Population changes, breeding cycles and breeding success over six years in seabird colony at Michaelmas Cay, Queensland. Emu 92: 1-10.

Klein, M. L., Humphrey, S. R. and Percival, H. F. (1995) Effects of ecotourism on distribution of waterbirds in a wildlife refuge. Conserv. Biol. 9: 1454-1465.

Klopfer, P. and Ganzhorn, J. U. (1985) Habitat selection: behavioral aspects. Pp. 435-453 in M. L. Cody, ed. Habitat selection in birds. Orlando, FL: Academic Press.

Lack, D. (1968) Ecological adaptations for breeding in birds. London: Methuen.

Licht, D. S. and Johnson, K. M. (1992) Black-billed Magpie predation on Piping Plover eggs. Prairie Nat. 24: 285.

Nager, R. G., Jonhson, A. R., Boy, V., Rendón-Martos, M., Calderón, J. and Cezilly, F. (1996) Temporal and spatial variation in dispersal in Greater Flamingo (Phoenicopterus ruber roseus). Oecologia 107: 204-211.

Nisbet, I. C. T. and Welton, M. J. (1984) Seasonal variation in breeding success of Common Terns: consequences of predation. Condor 86: 53-60.

Oltra, C. and Gómez, M. A. (1997) Amenazas humanas sobre las poblaciones nidificantes de limícolas en ecosistemas litorales. Pp. 175-200 in A. Barbosa, ed. Las aves limícolas de España. Madrid: Ed. Organismo Autónomo de Parques Nacionales.

Oro, D. (1996) Colonial seabird nesting in dense and small sub-colonies: an advantage against aerial predation. Condor 98: 850-854.

Piersma, T. (1996) Family Charadridae (Plovers). Pp. 384-443 in J. del Hoyo, A. Elliot and J. Sargatal, eds. Handbook of the birds of the world. Vol. 3. Hoatzin to Auks. Barcelona: Lynx Edicions. 
Powell, A. N. and Cuthbert, F. J. (1992) Habitat and reproductive success of Piping Plovers nesting on Great Lakes islands. Wilson Bull. 104: 155-161.

Safina, C., Burger, J. and Gochfeld, M. (1994) Occurrence of ants in nest of Roseate and Common Terns at Cedar Beach, New York. Colonial Waterbirds 17: 91-94.

Simmons, R. E., Cordes, I. and Braby, R. (1998) Latitudinal trends, population size and habitat preferences of the Damara Tern Sterna balaenarum on Namibia's desert coast. Ibis 140: $439-445$.

Thompson, B. C. and Slack, R. D. (1982) Physical aspects of colony selection by Least Terns on the Texas Coast. Colonial Waterbirds 5: 161-168.

USFWS (2000) Endangered Species Listing. Available at: http://www.fws.gov

Vidal, M. and Domínguez, J. (2000) Comportamiento del Chorlitejo Patinegro (Charadrius alexandrinus) ante perturbaciones antrópicas en una playa del NW ibérico. XV Jornadas Ornitológicas Españolas. El Rocío (Huelva). Dec. 2000.

Wittenberger, J. F. and Hunt, G. L. (1985) The adaptive significance of coloniality in birds. Pp. $1-78$ in D. S. Farner, J. R. King and K. C. Parker, eds. Avian biology. Vol. 8. New York: Academic Press.

Yorio, P. and Quintana, F. (1997) Predation by Kelp Gulls Larus dominicanus at a mixedspecies colony of Royal Terns Sterna maxima and Cayenne Terns Sterna eurygnatha in Patagonia. Ibis 139: 536-541.

Ziewitz, J. W., Sidle, J. G. and Dinan, J. J. (1992) Habitat conservation for nesting Least Terns and Piping Plovers on the Platte River, Nebraska. Prairie Nat. 24: 1-20.

Zusi, R. L. (1996) Family Rynchopidae (Skimmers). Pp. 668-677 in J. del Hoyo, A. Elliot and J. Sargatal, eds. Handbook of the birds of the world. Vol. 3. Hoatzin to Auks. Barcelona: Lynx Edicions.

\section{ANTONIO MUÑOZ DEL VIEJO* and JUAN MANUEL SÁNCHEZ}

Área de Zoología, Facultad de Ciencias, Universidad de Extremadura, Campus Universitario, Avenida de Elvas, s/n.06071, Badajoz, Spain.E-mail: amunoz@unex.es

XICOTÉNCATL VEGA

ITESM-Sinaloa, Boulevard Culiacán, Culiacán, Sinaloa, Mexico

MARCO A. GONZÁLEZ

Escuela de Biología, Universidad Autónoma de Sinaloa, Mexico

${ }^{*}$ Corresponding author.

Received 10 June 2002; revision accepted 18 March 2004 